\title{
Herbal Medicines and Infectious Diseases: Characterization by LC-SPE-NMR of Some Medicinal Plant Extracts Used against Malaria
}

Authors

Affiliations
Yong-jiang Xu ${ }^{1}$, Rica Capistrano I. ${ }^{1}$, Liene Dhooghe ${ }^{1}$, Kenn Foubert ${ }^{1}$, Filip Lemière ${ }^{2}$, Sheila Maregesi ${ }^{3}$, Aliou Baldé ${ }^{4}$, Sandra Apers ${ }^{1}$, Luc Pieters ${ }^{1}$

The affiliations are listed at the end of the article
Key words

- LC-SPE-NMR

- malaria

- Bafodeya benna

- Chrysobalanaceae

- Ormocarpum kirkii

- Papilionaceae

\section{Abstract \\ $\nabla$}

The extracts of two medicinal plants used in traditional medicine against malaria were characterized by means of an LC-SPE-NMR and LC-MS platform. The structure of a series of major constituents from Bafodeya benna, as well as minor constituents from Ormocarpum kirkii, was determined. Bafodeya benna was found to contain $(2 R, 3 R)$-taxifolin-3- 0 - $\alpha$-L-rhamnoside or astilbin, and its isomers neoastilbin, neoisoastilbin, and isoastilbin, as well as quercetin-3- $O$ - $\alpha$-L-rhamnoside. From Ormocarpum kirkii, a series of known flavonoids and biflavonoids was obtained, as well as three new compounds, i.e., 7,7"-di-O- $\beta$-D-glu-

\section{Introduction}

$\nabla$

For many years the Laboratory of Pharmacognosy and Pharmaceutical Analysis of the University of Antwerp has been involved in collaborative projects with research institutes and universities in developing countries, where traditional medicine still plays an important role in local health care systems. There are many infectious diseases, and although modern medicine is able to cope with most of them, they remain a major burden, especially in developing countries. Malaria is one of the most prominent examples. Especially the situation in Africa is problematic. Between 75 and 95\% of all malaria cases occur in the region between the Sahara and South Africa, and of all malaria deaths, $91 \%$ happen in Africa, mainly involving children under the age of 5 [1]. Therefore, the major focus of our research activities is on malaria, and especially on the situation in Africa. According to numbers of the World Health Organization (WHO), up to $80 \%$ of the population in some Asian and African countries depends on traditional medicine for their primary health care. This is in part due to limited access to synthetic cosyl-(-)-chamaejasmin, $7-0-\beta$-D-glucosyl-(I-3, II-3)-biliquiritigenin, and isovitexin-(I-3,II-3)-naringenin. The isolated constituents may explain, at least in part, the traditional use against malaria. LC-SPE-NMR, in combination with LC-MS, is a powerful tool for the fast characterization of plant extracts, in order to define priorities at an early stage of a fractionation procedure. In addition, herbal medicinal products can completely be characterized, both with regard to their major as well as their minor constituents.

Supporting information available online at http://www.thieme-connect.de/ejournals/toc/ plantamedica

drugs for logistic and economic reasons, but also for cultural reasons: indigenous people may also make a positive choice for traditional medicine because they believe in its healing power. For this reason the WHO has an active policy of integrating traditional medicine into local health care systems [2].

Two basic reasons can be advanced to work on medicinal plants. The first is to search for new lead compounds to be developed as drugs as such or, mostly, as synthetic or semisynthetic analogues. The second reason is the valorization of traditional medicine and herbal medicinal products. The use of plant preparations can be supported if it is safe and if their activity can be scientifically confirmed. This implies the need for quality control and standardization [3]. If the activity cannot be confirmed, and certainly if there is a risk of toxicity, the use of herbal medicinal products should be discouraged. Usually the risk of acute toxicity can be excluded, because in that case the use of a traditional preparation would not have continued over the years or even centuries, but chronic toxicity cannot be excluded since it is much more difficult to detect (this is also true 
for synthetic drugs). Both approaches can be represented in a flow chart ( $\odot$ Fig. 1, adapted from [4]). On the left side the classic process of bioassay-guided isolation of pure active compounds is shown, followed by the establishment of structure-activity relationships, toxicity and safety studies, and drug development. The right side shows the workflow when an herbal medicinal product is to be developed as such: firstly, analytical methods have to be established and validated based on active compounds if known, or on marker compounds if not or not yet. A parallel process of bioassay-guided isolation can help to assign the active constituents. Then standardized extracts can be prepared, subjected to toxicity and safety studies, and their efficacy can be investigated in clinical trials during the drug development stage ("Evidence Based Traditional Medicine"). Whereas the development of new drugs based on a lead compound usually is carried out by large multinational pharmaceutical companies, the production of standardized herbal medicinal products can be a way to promote local pharmaceutical industry in developing countries.

In spite of the benefits and potential of plant-based medicines, the process of bioassay-guided isolation can be rather time-consuming and laborious. Based on in vitro screens, active compounds can be easily overlooked. In addition, there is a high risk of obtaining known and/or uninteresting compounds, and the time and effort needed to isolate and to purify a known compound are the same as for a new compound. Much more efficient is to identify at an early stage of the isolation and purification procedure as many compounds as possible in the mixture, the crude plant extract. This concept is called "metabolomics", the analysis of the complete "metabolome", i.e., all metabolites, primary (carbohydrates, lipids, proteins) as well as secondary that are present in a given plant. Metabolomics involves the combination of up-to-date technologies such as LC-MS (liquid chromatography - mass spectrometry) and LC-NMR (liquid chromatography - nuclear magnetic resonance spectroscopy) with modern information technology such as PCA (principal component analysis) to process large amounts of data if needed. Drugs of plant origin are mainly secondary metabolites (polyketides, terpenes, alkaloids, etc.) and therefore in this context it is preferred to focus on these product classes (metabolomic profiling). The aim is to avoid the isolation of known or unwanted compounds and to pursue only the targeted isolation of compounds presenting promising spectroscopic features $[5,6]$. Whereas LC-MS is able to produce information based on the retention time, the molecular weight, and the fragmentation pattern (in MS/MS or MS ${ }^{\mathrm{n}}$ settings), little structural information is obtained. Its main advantage is the high sensitivity. Therefore, the coupling of LC with NMR is an excellent complementary method. With NMR spectroscopic data, certainly in combination with the molecular weight, an unambiguous identification is possible. However, the main disadvantage in this case is the low sensitivity. One of the possible strategies to circumvent this is the use of an SPE (Solid Phase Extraction) interface in an LC-SPE-NMR configuration [7]. Following chromatographic separation, the sample is collected fraction-wise on a battery of small SPE cartridges. By collecting during consecutive runs, the amount of material can be increased (multitrapping). After drying, the samples can then be eluted with deuterated solvents for NMR analysis. HPLC separation can be carried out using common solvents, and no expensive deuterated solvents are wasted. By using solvent suppression during NMR analysis, ${ }^{1} \mathrm{H}$ NMR spectra can be obtained on very low amounts of material, depending on the field strength of the spectrometer. After characterization of the most promising structures

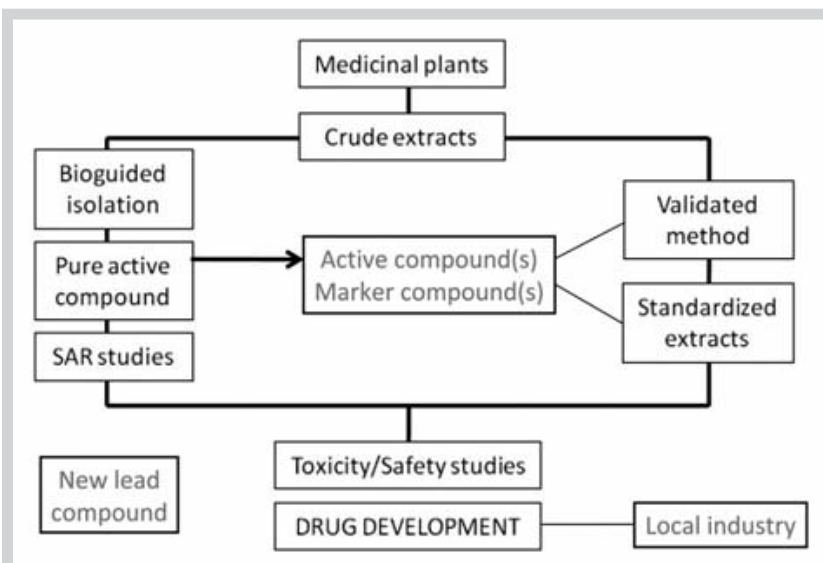

Fig. 1 Flow chart for the study of medicinal plants.

in the crude extract, preparative extraction and purification can immediately be focused on these constituents for more detailed investigations of their biological properties and to establish their structure-activity relationships.

In this work, LC-MS and LC-SPE-NMR were used in one integrated technology platform to investigate two plants used in traditional medicine in Africa, whose selection was based on ethnopharmacological investigations and screening of biological activities: Bafodeya benna (Scott-Elliot) Prance (Chrysobalanaceae) from Guinea-Conakry [8], for which no phytochemical information was available, and Ormocarpum kirkii S. Moore (Papilionaceae) from Tanzania $[9,10]$, from which a series of biflavonoids had been obtained, but whose minor constituents remained unidentified [11].

\section{Materials and Methods}

$\nabla$

\section{General experimental procedures}

Analytical grade solvents were obtained from Acros Organics. Water was prepared by reversed osmosis (RiOs; Millipore); for HPLC, MilliQ water (Millipore) was used. HPLC analysis was carried out on an Agilent 1200 series HPLC with degasser, quaternary pump, autosampler, column compartment with thermostat, and diode array detector. The LC-SPE-NMR configuration consisted of an Agilent 1200 series HPLC with degasser, quaternary pump, automatic injection and UV/VIS detection (variable wavelength). Samples were collected using a Bruker/Spark solid phase extraction system and prepared for NMR using a Gilson Liquid Handler 215. NMR spectra were recorded on a Bruker DRX $400 \mathrm{MHz}$ instrument operating at $400 \mathrm{MHz}$ for ${ }^{1} \mathrm{H}$, employing a 3-mm inverse broadband (BBI) probe or a $5-\mathrm{mm}$ dual ${ }^{1} \mathrm{H} /{ }^{13} \mathrm{C}$ probe using standard Bruker pulse sequences. LC-MS analysis was performed on a Surveyor LC system equipped with a diode array detector, which was coupled to a LXQ linear ion trap (Thermo Fisher). The experimental data were recorded in the (+) ESI mode using full scanning. All data were acquired and processed using Xcalibur software, version 2.0 (Thermo Fisher).

Positive ion mode accurate mass spectra were acquired using a Q-TOF II instrument (Waters). The MS was calibrated prior to use with a $0.02 \% \mathrm{H}_{3} \mathrm{PO}_{4}$ solution. Sample solutions $(10 \mu \mathrm{L})$ were injected using the CapLC system (Waters) and electrosprayed through the Nanomate (Advion) nanoelectrospray source. The 
Nanomate was operated in the positive ion mode at an electrospray potential of $1.5 \mathrm{kV}$. Samples were injected with an interval of 4 minutes. Before analysis and after each eighth sample, a $10-\mu \mathrm{L}$ volume of $0.02 \% \mathrm{H}_{3} \mathrm{PO}_{4}$ solution $\left(50 / 50 \mathrm{MeOH} / \mathrm{H}_{2} \mathrm{O}\right)$ was injected that could be used as lock mass. All measured masses were within a difference of 5 ppm compared to the calculated mass.

\section{Plant material}

Leaves from Bafodeya benna (Scott-Elliot) Prance were collected in Guinea-Conakry in 2010. The plant material was identified at the Centre de Recherche et de Valorisation des Plantes Médicinales de Dubréka, Guinea-Conakry (Prof. Aliou Baldé), where a voucher specimen is stored (MG-pb455). The root of Ormocarpum kirkii S. Moore was collected in the Bunda district in Tanzania $[9,10]$. Identification was performed at the Herbarium Unit, Botany Department of the University of Dar-Es-Salaam in Tanzania by Mr. Frank Mbago. A voucher specimen (BUNDA2000SM14) was deposited in the same herbarium.

\section{Extraction of compounds from Bafodeya benna}

Dried and pulverized leaves of B. benna (326 g) were extracted exhaustively with $\mathrm{MeOH} 80 \%$ (12 L). The extract was concentrated under reduced pressure below $40^{\circ} \mathrm{C}$, and finally lyophilized, yielding a residue of $69.35 \mathrm{~g}$. An amount of $66 \mathrm{~g}$ was dissolved in $300 \mathrm{~mL} \mathrm{MeOH} \mathrm{50 \% ,} \mathrm{concentrated} \mathrm{under} \mathrm{reduced} \mathrm{pres-}$ sure to remove $\mathrm{MeOH}$, diluted again with water to $300 \mathrm{~mL}$, and the $\mathrm{pH}$ was adjusted to 3 using $\mathrm{HCl} 2 \%$. The aqueous phase was extracted 3 times with $300 \mathrm{~mL} \mathrm{CHCl}$; all $\mathrm{CHCl}_{3}$ fractions were combined, concentrated under reduced pressure and washed with water ( $\mathrm{pH} 3$ ). All aqueous layers were combined. The $\mathrm{CHCl}_{3}$ layer was evaporated to dryness, dissolved in $200 \mathrm{~mL} \mathrm{MeOH} 90 \%$ and extracted 3 times with $200 \mathrm{~mL}$ petroleum ether. After concentration under reduced pressure, the petroleum ether layer was washed with $\mathrm{MeOH} 90 \%$, and all $\mathrm{MeOH} 90 \%$ fractions were combined. After evaporation to dryness, the residue from the petroleum ether fraction was denoted as fraction 1 (F1, 1.4 g), and the residue from the $\mathrm{MeOH} 90 \%$ fraction (after evaporation of $\mathrm{MeOH}$ and lyophilization) as fraction 2 (F2, $3.3 \mathrm{~g}$ ). The initial acidic aqueous fraction was adjusted to $\mathrm{pH} 9$ with $\mathrm{NH}_{4} \mathrm{OH} 25 \%$ and extracted 3 times with $500 \mathrm{~mL} \mathrm{CHCl}$. All $\mathrm{CHCl}_{3}$ fractions were combined, concentrated to $200 \mathrm{~mL}$ under reduced pressure and washed with water ( $\mathrm{pH} 9$ ). All aqueous layers were combined. After evaporation to dryness, the residue from the $\mathrm{CHCl}_{3}$ fraction was denoted as fraction 3 (F3, $1.3 \mathrm{~g}$ ) and the residue from the aqueous fraction (after lyophilization) as fraction 4 (F4, 44.6 g).

In order to remove tannins and polysaccharides, $5.21 \mathrm{~g}$ of F4 was dissolved in $70 \mathrm{~mL}$ EtOH $50 \%$. Polysaccharides were removed by filtration, and the filtrate was concentrated under reduced pressure. MN Polyamide SC 0.05-0.016 mm (Macherey-Nagel) (136 g) was preconditioned with $\mathrm{MeOH}(300 \mathrm{~mL}), \mathrm{MeOH} 50 \%(300 \mathrm{~mL})$, and finally $\mathrm{H}_{2} \mathrm{O}(300 \mathrm{~mL})$. The filtrate was mixed with the aqueous polyamide suspension and stirred for $10 \mathrm{~min}$. After filtration, tannins were retained by the polyamide material while all other constituents were eluted with $\mathrm{H}_{2} \mathrm{O}(2 \times 300 \mathrm{~mL})$. A total amount of $2.35 \mathrm{~g}$ tannin-free $\mathrm{F} 4$ was obtained. The four fractions were investigated by means of TLC and HPLC-DAD in comparison to the TLC profile and HPLC chromatogram of the crude extract. Analytical TLC was carried out on normal phase silica gel $60 \mathrm{~F}_{254}$ plates (Merck) using $\mathrm{CHCl}_{3}: \mathrm{MeOH}(3: 1)$ as the mobile phase, and reversed phase silica gel $60 \mathrm{RP}-18 \mathrm{~F}_{254}$ plates (Merck) using $\mathrm{MeOH}: \mathrm{H}_{2} \mathrm{O}(1: 1)$. Samples of $10 \mu \mathrm{L}$ of $15 \mathrm{mg} / \mathrm{mL}$ solutions were spotted on the TLC plates and were developed. Anisaldehyde (0.5 mL; Sigma-Aldrich) dissolved in $10 \mathrm{~mL}$ acetic acid, $85 \mathrm{~mL}$ methanol, and $5 \mathrm{~mL}$ sulfuric acid, and phosphomolybdic acid ( $5 \mathrm{~g}$; Sigma-Aldrich) dissolved in $50 \mathrm{~mL}$ ethanol 96\%, were used as spraying reagents. Analytical separations on HPLC-DAD were carried out on a GraceSmart ${ }^{\circledR} \mathrm{RP} 18$ column, $5 \mu \mathrm{m}, 250 \times 4.6 \mathrm{~mm}$ column (Grace), using a gradient with $0.05 \%$ trifluoroacetic acid (TFA) in water (A) and methanol (B): $0 \mathrm{~min}, 90: 10$ (A:B); $45 \mathrm{~min}$, $0: 100$. Samples of $5 \mu \mathrm{L}$ of $5 \mathrm{mg} / \mathrm{mL}$ solutions in $\mathrm{MeOH} 50 \%$ were injected. Flow rate was $1.0 \mathrm{~mL} / \mathrm{min}$, the temperature of the column compartment $20^{\circ} \mathrm{C}$, and the peaks were detected at several wavelengths ranging from 210 to $366 \mathrm{~nm}$.

Finally, the compounds present in fraction 4 were isolated and identified using LC-SPE-NMR. The same analytical HPLC column and solvents were used as mentioned above for HPLC-DAD. The gradient was optimized to isolate the five components: 0 min, 65 : 35 (A:B); $18 \mathrm{~min}, 56: 44 ; 25 \mathrm{~min}, 38: 62$. This allowed injection of up to $80 \mu \mathrm{L}$ of a $20 \mathrm{mg} / \mathrm{mL}$ solution (in $\mathrm{MeOH} 50 \%$ ). The peaks with the following retention times, detected at $290 \mathrm{~nm}$, were repeatedly collected on the SPE cartridges during 5 consecutive runs: 13.7 min (compound 1), $14.4 \mathrm{~min}$ (compound 2), $15.2 \mathrm{~min}$ (compound 3), $16.2 \mathrm{~min}$ (compound 4), and $23.0 \mathrm{~min}$ (compound 5). After drying of the cartridges, the components were eluted using $\mathrm{CD}_{3} \mathrm{CN}(99.8 \% \mathrm{D}$, Aldrich), and NMR spectra were recorded. In addition, LC-MS analysis was performed on each sample.

(2S,3S)-Taxifolin-3-O- $\alpha$-L-rhamnoside (neoastilbin) (1). ${ }^{1} \mathrm{H}$ and ${ }^{13} \mathrm{C}$ NMR: Table 1S and 2S (Supporting Information). ESI-MS: $m / z 473$ $\left([\mathrm{M}+\mathrm{Na}]^{+}\right), 451\left([\mathrm{M}+\mathrm{H}]^{+}\right), 305\left([\mathrm{M}-146+\mathrm{H}]^{+}\right)$.

(2R,3R)-Taxifolin-3-O- $\alpha$-L-rhamnoside (astilbin) (2). ${ }^{1} \mathrm{H}$ and ${ }^{13} \mathrm{C}$ NMR: Table 1S and 2S (Supporting Information). ESI-MS: $m / z$ $473\left([\mathrm{M}+\mathrm{Na}]^{+}\right), 451\left([\mathrm{M}+\mathrm{H}]^{+}\right), 305\left([\mathrm{M}-146+\mathrm{H}]^{+}\right)$.

(2S,3R)-Taxifolin-3-O- $\alpha$-L-rhamnoside (neoisoastilbin) (3). ${ }^{1} \mathrm{H}$ and ${ }^{13} \mathrm{C}$ NMR: Table $1 \mathrm{~S}$ and $2 \mathrm{~S}$ (Supporting Information). ESI-MS: $\mathrm{m} / \mathrm{z}$ $473\left([\mathrm{M}+\mathrm{Na}]^{+}\right), 451\left([\mathrm{M}+\mathrm{H}]^{+}\right), 305\left([\mathrm{M}-146+\mathrm{H}]^{+}\right)$.

(2R,3S)-Taxifolin-3-O- $\alpha$-L-rhamnoside (isoastilbin) (4). ${ }^{1} \mathrm{H}$ NMR: Table 1S (Supporting Information). ESI-MS: $m / z 473\left([\mathrm{M}+\mathrm{Na}]^{+}\right)$, $451\left([\mathrm{M}+\mathrm{H}]^{+}\right), 305\left([\mathrm{M}-146+\mathrm{H}]^{+}\right)$.

Quercetin-3-O- $\alpha$-L-rhamnoside (5). ${ }^{1} \mathrm{H}$ and ${ }^{13} \mathrm{C}$ NMR: Table $1 \mathrm{~S}$ and 2S (Supporting Information). ESI-MS: $m / z 471\left([\mathrm{M}+\mathrm{Na}]^{+}\right), 449$ $\left([\mathrm{M}+\mathrm{H}]^{+}\right), 303\left([\mathrm{M}-146+\mathrm{H}]^{+}\right)$.

\section{Extraction of compounds from Ormocarpum kirkii}

Roots of 0 . kirkii were dried and ground to a powder. The powdered material $(1.35 \mathrm{~kg}$ ) was exhaustively extracted with $\mathrm{MeOH}$ $80 \%$ (20 L), and the combined, concentrated $\mathrm{MeOH}$ extract $(220 \mathrm{~g})$ was partitioned with $n$-hexane (yielding a residue of $2.81 \mathrm{~g}$ ), chloroform (3.06 g), EtOAc (61.03 g), and water (132.75 g) (each solvent $3 \times 300 \mathrm{~mL}$ ). The EtOAc fraction was subjected to column chromatography on silica gel, and ten fractions (EA01 to EA10) were obtained [11].

HPLC analysis of the crude extract, the chloroform fraction, the EtOAc and water fractions were carried out on a Zorbax Eclipse XDB-C18 $5 \mu \mathrm{m}$ column from Agilent $(150 \times 4.6 \mathrm{~mm})$ with UV detection at $280 \mathrm{~nm}$. The temperature of the column compartment was set at $20^{\circ} \mathrm{C}$, and separation was obtained using a gradient with $0.05 \%$ TFA in water (A) and acetonitrile (B) at a flow rate of $1.0 \mathrm{~mL} / \mathrm{min}$ : $0 \mathrm{~min}, 80: 20$ (A:B); $5 \mathrm{~min}, 80: 20 ; 30 \mathrm{~min} \mathrm{20:80.}$ Samples of $5 \mu \mathrm{L}$ of $50 \mathrm{mg} / \mathrm{mL}$ solutions in $\mathrm{MeOH}$ were injected.

The HPLC chromatogram of the chloroform fraction showed five major peaks. These peaks were then analyzed using LC-SPE-NMR. The same conditions were used as for the HPLC analysis described above, only the gradient was adjusted in order to obtain 
Table $1{ }^{1} \mathrm{H}$ NMR assignments for compounds 15-18 (recorded in $\mathrm{CD}_{3} \mathrm{OD}$ ).

\begin{tabular}{|lllll}
\hline H No. $\mathbf{1 5}$ & $\mathbf{1 6}$ & $\mathbf{1 7}$ & $\mathbf{1 8}$ \\
\hline 2 & $5.83(\mathrm{~d}, \mathrm{~J}=12)$ & $5.83(\mathrm{~d}, J=12)$ & $5.83(\mathrm{~d}, J=12)$ & $5.93(\mathrm{~d}, J=12)$ \\
\hline 3 & $2.86(\mathrm{~d}, J=12)$ & $2.86(\mathrm{~d}, J=12)$ & $2.68(\mathrm{~d}, J=12)$ & $4.17(\mathrm{~d}, J=12)$ \\
\hline 5 & - & - & $7.68(\mathrm{~d}, J=8)$ & - \\
\hline 6 & $6.22(\mathrm{~d}, J=4)$ & $6.20(\mathrm{~d}, J=4)$ & $6.50(\mathrm{dd}, J=2,8)$ & $* 5.96(\mathrm{~m})$ \\
\hline 8 & $6.16(\mathrm{~d}, J=4)$ & $6.15(\mathrm{~d}, J=4)$ & $6.26(\mathrm{~d}, J=2)$ & $* 5.88(\mathrm{~m})$ \\
\hline $2^{\prime}$ & $6.93(\mathrm{~d}, J=8)$ & $6.93(\mathrm{~d}, J=8)$ & $6.93(\mathrm{~d}, J=8)$ & $6.80(\mathrm{~d}, J=8)$ \\
\hline $3^{\prime}$ & $6.80(\mathrm{~d}, J=8)$ & $6.80(\mathrm{~d}, J=8)$ & $6.79(\mathrm{~d}, J=8)$ & $6.58(\mathrm{~d}, J=8)$ \\
\hline $5^{\prime}$ & $6.80(\mathrm{~d}, J=8)$ & $6.80(\mathrm{~d}, J=8)$ & $6.79(\mathrm{~d}, J=8)$ & $6.58(\mathrm{~d}, J=8)$ \\
\hline $6^{\prime}$ & $6.93(\mathrm{~d}, J=8)$ & $6.93(\mathrm{~d}, J=8)$ & $6.93(\mathrm{~d}, J=8)$ & $6.80(\mathrm{~d}, J=8)$ \\
\hline $2^{\prime \prime}$ & - & - & $5.88(\mathrm{~d}, J=12)$ & - \\
\hline $3^{\prime \prime}$ & - & - & $2.70(\mathrm{~d}, J=12)$ & - \\
\hline $5^{\prime \prime}$ & - & - & $7.87(\mathrm{~d}, J=8)$ & - \\
\hline $6^{\prime \prime}$ & - & - & $6.77(\mathrm{dd}, \mathrm{J}=2,8)$ & - \\
\hline $8^{\prime \prime}$ & - & - & $6.61(\mathrm{~d}, J=2)$ & $6.31(\mathrm{~s})$ \\
\hline $2^{\prime \prime \prime}$ & - & - & $6.93(\mathrm{~d}, J=8)$ & $6.99(\mathrm{~d}, J=8)$ \\
\hline $3^{\prime \prime \prime}$ & - & - & $6.79(\mathrm{~d}, J=8)$ & $6.83(\mathrm{~d}, J=8)$ \\
\hline $5^{\prime \prime \prime}$ & - & - & $6.79(\mathrm{~d}, J=8)$ & $6.83(\mathrm{~d}, J=8)$ \\
\hline $6^{\prime \prime \prime}$ & - & - & $6.93(\mathrm{~d}, J=8)$ & $6.99(\mathrm{~d}, J=8)$ \\
\hline $1^{\prime \prime \prime \prime}$ & $4.97(\mathrm{~d}, J=8)$ & $4.99(\mathrm{~d}, J=8)$ & $4.97(\mathrm{~d}, J=8)$ & $4.89(\mathrm{~d}, J=8)$ \\
\hline $2^{\prime \prime \prime \prime}$ & $3.44(\mathrm{~m})$ & $3.44(\mathrm{~m})$ & $3.44(\mathrm{~m})$ & $3.44(\mathrm{~m})$ \\
\hline $3^{\prime \prime \prime \prime}$ & $3.41(\mathrm{~m})$ & $3.42(\mathrm{~m})$ & $3.44(\mathrm{~m})$ & $3.43(\mathrm{~m})$ \\
\hline $4^{\prime \prime \prime \prime}$ & $3.46(\mathrm{~m})$ & $3.46(\mathrm{~m})$ & $3.44(\mathrm{~m})$ & $3.46(\mathrm{~m})$ \\
\hline $5^{\prime \prime \prime \prime}$ & $3.47(\mathrm{~m})$ & $3.47(\mathrm{~m})$ & $3.45(\mathrm{~m})$ & $3.48(\mathrm{~m})$ \\
\hline $6^{\prime \prime \prime \prime}$ & $3.89(\mathrm{~m})$ & $3.87(\mathrm{~m})$ & $3.85(\mathrm{~m})$ & $3.87(\mathrm{~m})$ \\
& $3.68(\mathrm{~m})$ & $3.68(\mathrm{~m})$ & $3.67(\mathrm{~m})$ & $3.73(\mathrm{~m})$ \\
\hline & & & & \\
\hline
\end{tabular}

* Overlapping signals

a good separation for more concentrated samples: 0 min, $80: 20$ (A:B); $5 \mathrm{~min}, 70: 30 ; 60 \mathrm{~min}, 20: 80$. The injection volume was increased up to $20 \mu \mathrm{L}$. Using the multitrapping function, the following peaks were repeatedly collected during 20 consecutive runs: 19.9 min (compound 6), $23.6 \mathrm{~min}$ (compound 7), $24.7 \mathrm{~min}$ (compound 8), $29.9 \mathrm{~min}$ (compound 9), and $39.3 \mathrm{~min}$ (compound 10).

For the LC-SPE-NMR analysis of fraction EA08, similar conditions were used as for the analysis of the chloroform fraction. However, $0.05 \%$ TFA in water (A) and methanol (B) were used as the mobile phase with the following gradient: $0 \mathrm{~min}, 80: 20$ (A:B); $20 \mathrm{~min}$, $60: 40$; $30 \mathrm{~min}, 57: 43 ; 65 \mathrm{~min}, 60: 40$; $70 \mathrm{~min}, 0: 100$. A total of 9 compounds were repeatedly collected during 40 injections: $6.5 \mathrm{~min}$ (compound 11), $11.6 \mathrm{~min}$ (compound 12), $12.8 \mathrm{~min}$ (compound 13), $17.2 \mathrm{~min}$ (compound 14), $18.68 \mathrm{~min}$ (compound 15), $21.8 \mathrm{~min}$ (compound 16), $23.9 \mathrm{~min}$ (compound 17), $26.4 \mathrm{~min}$ (compound 18), and $33.7 \mathrm{~min}$ (compound 19).

The loaded SPE cartridges were dried, the components were eluted using $\mathrm{CD}_{3} \mathrm{OD}(99.8 \% \mathrm{D}$; Aldrich) and transferred into $3 \mathrm{~mm}$ NMR tubes, and NMR spectra were recorded. In addition, LC-MS analysis was performed on each sample. ${ }^{1} \mathrm{H}$ and ${ }^{13} \mathrm{C}$ NMR spectra of compounds 15-18 are available as Supporting Information (Fig. 1S-8S).

(+)-Chamaejasmin (6). ${ }^{1} \mathrm{H}$ NMR as in [11]. ESI-MS: $m / z 543$ $\left([\mathrm{M}+\mathrm{H}]^{+}\right)$.

Diphysolone (7). ${ }^{1} \mathrm{H}$ and ${ }^{13} \mathrm{C}$ NMR as in [22]. ESI-MS: $m / z 357$ $\left([\mathrm{M}+\mathrm{H}]^{+}\right)$.

Glabroisoflavanone $A(8) .{ }^{1} \mathrm{H}$ and ${ }^{13} \mathrm{C}$ NMR as in [23]. ESI-MS: $\mathrm{m} / \mathrm{z}$ $339\left([\mathrm{M}+\mathrm{H}]^{+}\right)$.

Sikokianin $B(9) .{ }^{1} \mathrm{H}$ and ${ }^{13} \mathrm{C}$ NMR as in [24]. ESI-MS: $m / z 557$ $\left([\mathrm{M}+\mathrm{H}]^{+}\right)$.

Chamaejasmenin $B(\mathbf{1 0}) .{ }^{1} \mathrm{H}$ NMR as in [25]. ESI-MS: $m / z 571$

$\left([\mathrm{M}+\mathrm{H}]^{+}\right)$.
Table $2{ }^{13} \mathrm{C}$ NMR assignments for compounds 15-18 (recorded in $\mathrm{CD}_{3} \mathrm{OD}$ ).

\begin{tabular}{|c|c|c|c|c|}
\hline C No. & 15 & 16 & 17 & 18 \\
\hline 2 & $85.1 \mathrm{CH}$ & $85.1 \mathrm{CH}$ & $85.8 \mathrm{CH}$ & $82.7 \mathrm{CH}$ \\
\hline 3 & $51.5 \mathrm{CH}$ & $51.4 \mathrm{CH}$ & $52.5 \mathrm{CH}$ & $54.1 \mathrm{CH}$ \\
\hline 4 & 198.7 qC & $198.6 \mathrm{qC}$ & $193.9 \mathrm{qC}$ & $197.7 q C$ \\
\hline 5 & $164.9 \mathrm{qC}$ & $164.8 \mathrm{qC}$ & $130.3 \mathrm{CH}$ & $165.1 \mathrm{qC}$ \\
\hline 6 & $98.4 \mathrm{CH}$ & $98.3 \mathrm{CH}$ & $112.5 \mathrm{CH}$ & $97.5 \mathrm{CH}$ \\
\hline 7 & $167.1 \mathrm{qC}$ & $166.8 \mathrm{qC}$ & $166.7 q C$ & $168.3 q C$ \\
\hline 8 & $97.0 \mathrm{CH}$ & $96.9 \mathrm{CH}$ & $103.7 \mathrm{CH}$ & $96.4 \mathrm{CH}$ \\
\hline 9 & $164.1 \mathrm{qC}$ & $164.1 \mathrm{qC}$ & $164.5 \mathrm{qC}$ & $164.7 \mathrm{qC}$ \\
\hline 10 & $105.0 \mathrm{qC}$ & $105.0 \mathrm{qC}$ & $118.3 \mathrm{qC}$ & $103.0 \mathrm{qC}$ \\
\hline $1^{\prime}$ & $128.8 \mathrm{qC}$ & $128.7 \mathrm{qC}$ & $129.8 \mathrm{qC}$ & $130.0 \mathrm{qC}$ \\
\hline $2^{\prime}$ & $130.4 \mathrm{CH}$ & $130.4 \mathrm{CH}$ & $130.4 \mathrm{CH}$ & $129.4 \mathrm{CH}$ \\
\hline $3^{\prime}$ & $116.7 \mathrm{CH}$ & $116.6 \mathrm{CH}$ & $116.5 \mathrm{CH}$ & $116.1 \mathrm{CH}$ \\
\hline $4^{\prime}$ & $159.6 \mathrm{qC}$ & $159.6 \mathrm{qC}$ & *159.4 qC & $158.5 q C$ \\
\hline $5^{\prime}$ & $116.7 \mathrm{CH}$ & $116.6 \mathrm{CH}$ & $116.6 \mathrm{CH}$ & $116.1 \mathrm{CH}$ \\
\hline $6^{\prime}$ & $130.4 \mathrm{CH}$ & $130.4 \mathrm{CH}$ & $130.4 \mathrm{CH}$ & $129.4 \mathrm{CH}$ \\
\hline $2^{\prime \prime}$ & - & - & $85.8 \mathrm{CH}$ & $167.9 q C$ \\
\hline $3^{\prime \prime}$ & - & - & $52.6 \mathrm{CH}$ & $115.3 q C$ \\
\hline $4^{\prime \prime}$ & - & - & $193.6 \mathrm{qC}$ & $182.5 \mathrm{qC}$ \\
\hline $5^{\prime \prime}$ & - & - & $130.2 \mathrm{CH}$ & $162.2 \mathrm{qC}$ \\
\hline $6^{\prime \prime}$ & - & - & $111.9 \mathrm{CH}$ & $109.2 \mathrm{qC}$ \\
\hline $7^{\prime \prime}$ & - & - & $165.5 \mathrm{qC}$ & $165.6 \mathrm{qC}$ \\
\hline $8^{\prime \prime}$ & - & - & ${ }^{*} 102.9 \mathrm{CH}$ & $94.9 \mathrm{CH}$ \\
\hline $9^{\prime \prime}$ & - & - & $164.5 \mathrm{qC}$ & $159.0 \mathrm{qC}$ \\
\hline $10^{\prime \prime}$ & - & - & $117.3 \mathrm{qC}$ & $105.0 \mathrm{qC}$ \\
\hline $1^{\prime \prime \prime}$ & - & - & $129.5 \mathrm{qC}$ & $124.1 \mathrm{qC}$ \\
\hline $2^{\prime \prime \prime}$ & - & - & $130.3 \mathrm{CH}$ & $131.5 \mathrm{CH}$ \\
\hline $3^{\prime \prime \prime}$ & - & - & $117.2 \mathrm{CH}$ & $116.5 \mathrm{CH}$ \\
\hline $4^{\prime \prime \prime}$ & - & - & *159.4 qC & $161.3 q C$ \\
\hline $5^{\prime \prime \prime}$ & - & - & $117.2 \mathrm{CH}$ & $116.5 \mathrm{CH}$ \\
\hline $6^{\prime \prime \prime}$ & - & - & $130.3 \mathrm{CH}$ & $131.5 \mathrm{CH}$ \\
\hline $1^{\prime \prime \prime \prime}$ & $101.3 \mathrm{CH}$ & $101.1 \mathrm{CH}$ & $101.6 \mathrm{CH}$ & $75.3 \mathrm{CH}$ \\
\hline $2^{\prime \prime \prime \prime}$ & $74.6 \mathrm{CH}$ & $74.6 \mathrm{CH}$ & $74.8 \mathrm{CH}$ & $72.1 \mathrm{CH}$ \\
\hline $3^{\prime \prime \prime \prime}$ & $78.2 \mathrm{CH}$ & $78.2 \mathrm{CH}$ & $78.3 \mathrm{CH}$ & $80.2 \mathrm{CH}$ \\
\hline $4^{\prime \prime \prime \prime \prime}$ & $71.1 \mathrm{CH}$ & $71.1 \mathrm{CH}$ & $71.3 \mathrm{CH}$ & $72.6 \mathrm{CH}$ \\
\hline $5^{\prime \prime \prime \prime}$ & $77.7 \mathrm{CH}$ & $77.7 \mathrm{CH}$ & $77.9 \mathrm{CH}$ & $82.5 \mathrm{CH}$ \\
\hline $6^{\prime \prime \prime \prime}$ & $62.2 \mathrm{CH}$ & $62.2 \mathrm{CH}$ & $62.4 \mathrm{CH}$ & $62.9 \mathrm{CH}$ \\
\hline
\end{tabular}

* Observed in an HMBC experiment

7-O- $\beta$-D-Glucosyldiphysin (11). ${ }^{1} \mathrm{H}$ NMR as in [11]. ESI-MS: $m / z$ $705\left([\mathrm{M}+\mathrm{Na}]^{+}\right)$.

Montanoside (12). ${ }^{1} \mathrm{H}$ and ${ }^{13} \mathrm{C}$ NMR as in [26]. ESI-MS: $m / z 603$ $\left([\mathrm{M}+\mathrm{Na}]^{+}\right)$.

Naringin (13). ${ }^{1} \mathrm{H}$ and ${ }^{13} \mathrm{C}$ NMR as in [27]. ESI-MS: $m / z 603$ $\left([\mathrm{M}+\mathrm{Na}]^{+}\right)$.

Isovitexin (14). ${ }^{1} \mathrm{H}$ NMR as in [11]. ESI-MS: $m / z 455\left([\mathrm{M}+\mathrm{Na}]^{+}\right)$.

7,7"-Di-O- $\beta$-D-glucosylchamaejasmin (15). ${ }^{1} \mathrm{H}$ and ${ }^{13} \mathrm{C}$ NMR: $\odot$ Ta-

bles 1 and 2. ESI-MS: $m / z 889\left([\mathrm{M}+\mathrm{Na}]^{+}\right)$.

7,7"-Di-O- $\beta$-D-glucosyl-(-)-chamaejasmin (16). ${ }^{1} \mathrm{H}$ and ${ }^{13} \mathrm{C}$ NMR:

- Tables 1 and 2. ESI-MS: $m / z 889\left([\mathrm{M}+\mathrm{Na}]^{+}\right)$. HR-ESI-MS: $\mathrm{m} / z$ $867.2380\left([\mathrm{M}+\mathrm{H}]^{+}\right)$(calcd. for $\mathrm{C}_{42} \mathrm{H}_{43} \mathrm{O}_{20}+$ : 867.2348).

7-O- $\beta$-D-Glucosyl-(I-3,II-3)-biliquiritigenin (17). ${ }^{1} \mathrm{H}$ and ${ }^{13} \mathrm{C}$ NMR:

- Tables 1 and 2. ESI-MS: $m / z 695\left([\mathrm{M}+\mathrm{Na}]^{+}\right)$. HR-ESI-MS: $m / z$

$673.1940\left([\mathrm{M}+\mathrm{H}]^{+}\right)$(calcd. for $\mathrm{C}_{36} \mathrm{H}_{33} \mathrm{O}_{13}{ }^{+}$: 673.1921).

Isovitexin-(I-3,II-3)- naringenin (18). ${ }^{1} \mathrm{H}$ and ${ }^{13} \mathrm{C}$ NMR: $\triangle$ Tables 1

and 2. ESI-MS: $m / z 725\left([\mathrm{M}+\mathrm{Na}]^{+}\right)$. HR-ESI-MS: $m / z 703.1696$ ([M

$+\mathrm{H}]^{+}$) (calcd. for $\mathrm{C}_{36} \mathrm{H}_{31} \mathrm{O}_{15}{ }^{+}:$703.1663).

7-O- $\beta$-D-Glucosylchamaejasmin (19). ${ }^{1} \mathrm{H}$ NMR see reference [11]. ESI-MS: $m / z 727\left([\mathrm{M}+\mathrm{Na}]^{+}\right)$ 


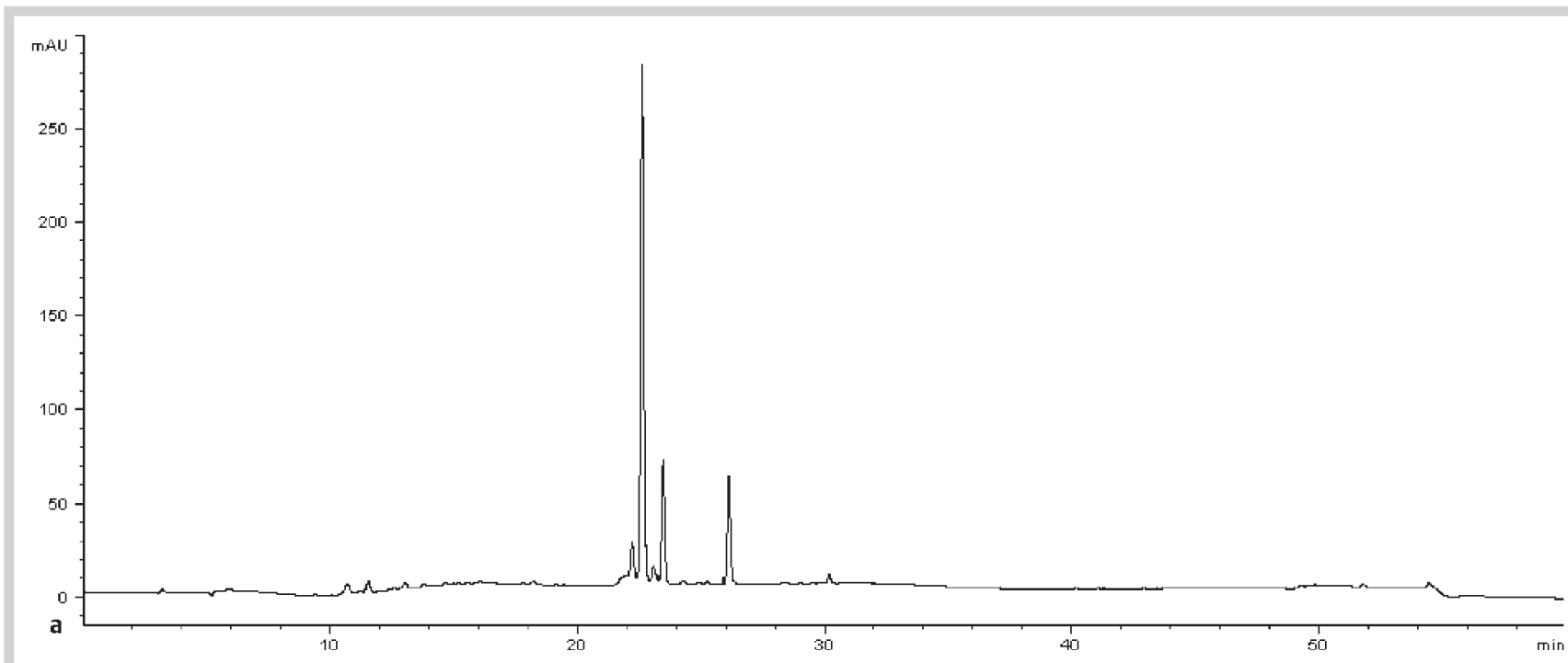

Fig. 2a HPLC profile of the crude extract of Bafodeya benna using 0.05\% TFA in water (A) and MeOH (B): 0 min, $90: 10$ (A: B); $45 \mathrm{~min}, 0: 100 ;$ at $1.0 \mathrm{~mL} / \mathrm{min}$ on a GraceSmart RP18 column, $5 \mu \mathrm{m}, 250 \times 10 \mathrm{~mm}$ with detection at $290 \mathrm{~nm}$.

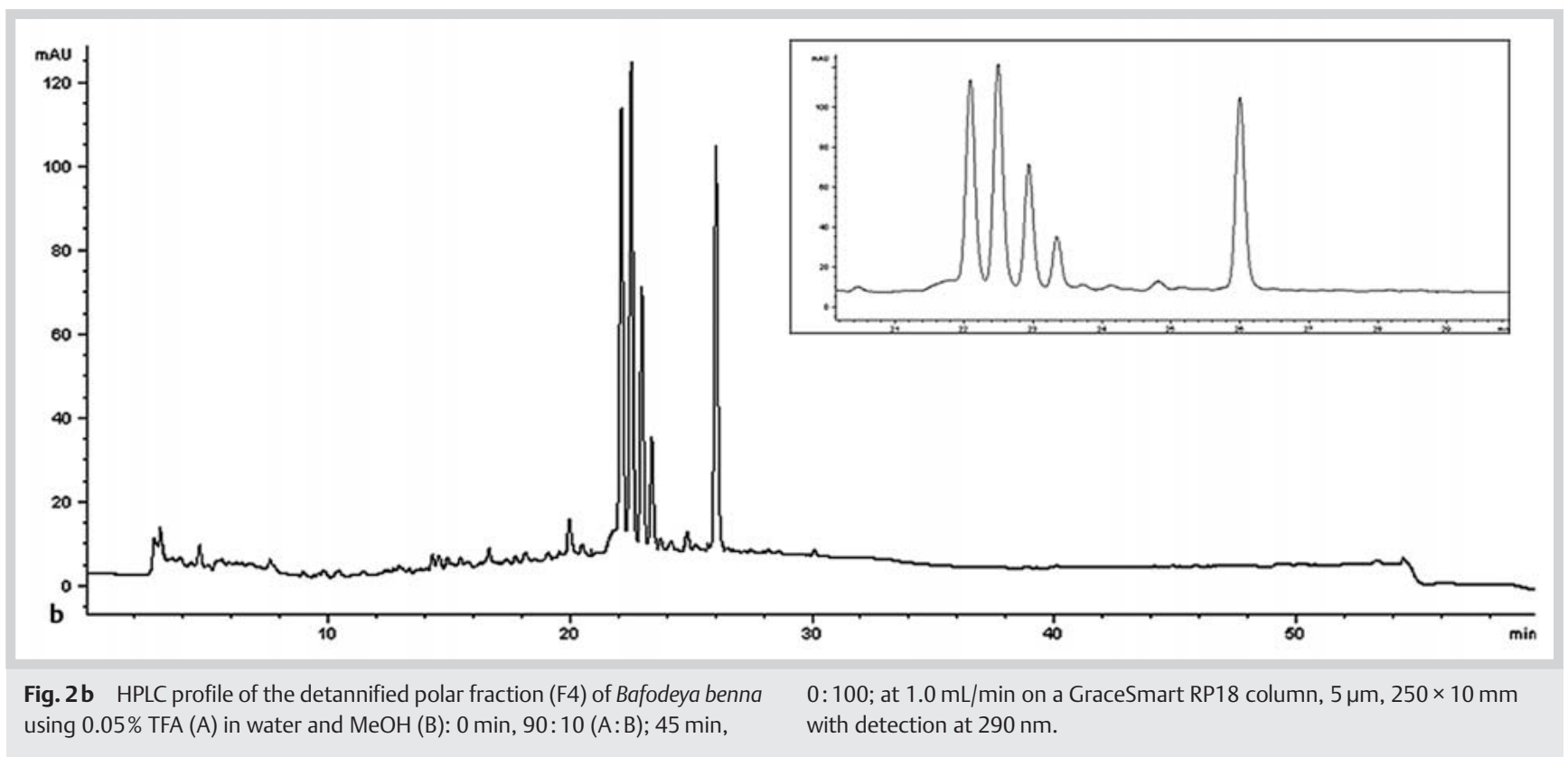

\section{Supporting information}

${ }^{1} \mathrm{H}$ and ${ }^{13} \mathrm{C}$ NMR spectra of compounds $15-18$ and NMR data for compounds 1-5 are available as Supporting Information.

\section{Results and Discussion}

$\nabla$

Fractionation of the crude extract of Bafodeya benna afforded a petroleum ether extract, F1, and two fractions of intermediate polarity, F2 and F3, in a rather low amount. According to the TLC pattern, color development with spraying reagents, and the fact that foaming was observed, it could be deduced that F2 and F3 were complex mixtures of saponins. In view of the low amount obtained for fractions F1, F2, and F3, priority was given to the phytochemical investigation of the polar fraction $\mathrm{F} 4$, for which a large amount was obtained. Removal of tannins resulted in a loss of about $50 \%$ of the dry weight of this fraction. The HPLC chromatogram of the crude extract and the detannified polar fraction F4 are shown in $\mathbf{O}$ Fig. $\mathbf{2} \mathbf{a}$ and $\mathbf{2} \mathbf{b}$, respectively. Both chromatograms essentially show the same peaks, although the proportions are different, as will be discussed below. The detannified fraction F4 was subjected to LC-SPE-NMR using the same analytical column. All five peaks were collected; ${ }^{1} \mathrm{H}$ NMR and HSQC spectra were recorded using 3-mm tubes on the 3-mm indirect detection probe, ${ }^{13} \mathrm{C}$ NMR spectra using 3 -mm tubes in the $5-\mathrm{mm}$ dual ${ }^{1} \mathrm{H} /$ ${ }^{13} \mathrm{C}$ probe. Compounds $1-4$ showed similar ${ }^{1} \mathrm{H}$ and ${ }^{13} \mathrm{C}$ NMR spectra, indicating four isomers. They could be identified as dihydroflavonols, i.e., taxifolin isomers, substituted in position 3 with a rhamnosyl moiety, by comparison with literature data ( $\odot$ Fig. 3 ). Compound $\mathbf{1}$ was identified as (2S,3S)-taxifolin-3-O- $\alpha$-L-rham- 


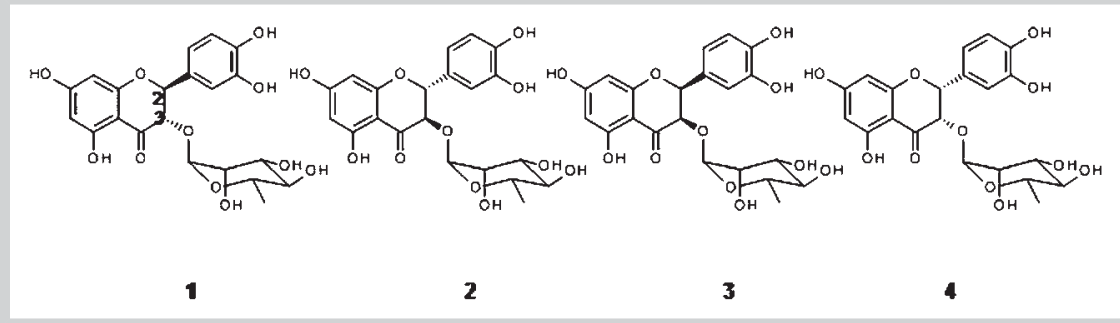

Fig. 3 Neoastilbin (1), astilbin (2), neoisoastilbin (3), and isoastilbin (4) from Bafodeya benna.

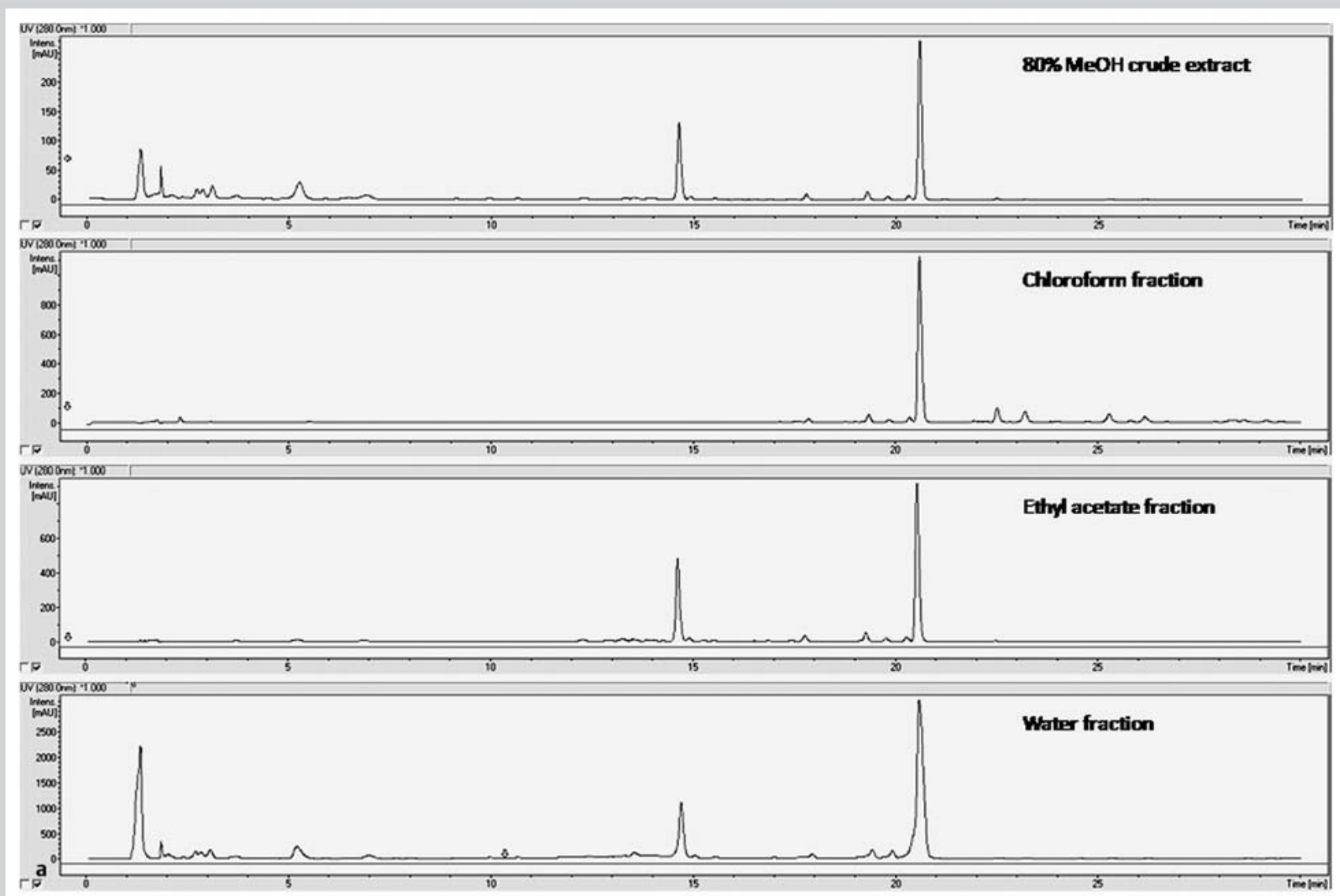

Fig. 4a HPLC profile of the crude extract and the fractions of Ormocarpum kirkii using $0.05 \%$ TFA in water $(\mathrm{A})$ and $\mathrm{CH}_{3} \mathrm{CN}(\mathrm{B}): 0$ min, $80: 20$ (A:B); 5 min,
$80: 20 ; 30 \mathrm{~min} 20: 80$; at $1.0 \mathrm{~mL} / \mathrm{min}$ on a Zorbax Eclipse XDB-C18 column, $5 \mu \mathrm{m}, 150 \times 4.6 \mathrm{~mm}$ with detection at $280 \mathrm{~nm}$. noside or neoastilbin, compound 2 as $(2 R, 3 R)$-taxifolin-3- $O-\alpha$ - Lrhamnoside or astilbin, compound 3 as (2S,3R)-taxifolin-3- $O-\alpha$-Lrhamnoside or neoisoastilbin, and compound 4 as (2R,3S)-taxifolin-3-0- $\alpha$-L-rhamnoside or isoastilbin [12-16]. The trans-configuration of the heterocyclic ring can be deduced from the large coupling constant between $\mathrm{H}-2$ and $\mathrm{H}-3$ (about $11 \mathrm{~Hz}$ ), whereas in the cis-isomers only a small coupling is observed (about $2 \mathrm{~Hz}$ ). The absolute configuration of the compounds was deduced from previous reports on the elution order of these isomers after HPLC analysis of Smilax glabra using a C18 column [16]. The remaining compound 5 could be identified as quercetin-3-O- $\alpha$-L-rhamnoside [17]. Comparing the HPLC profiles of the crude extract and the detannified polar fraction F4, it appears that isomerization has occurred during the fractionation procedure. In the crude extract, compound 2, i.e., $(2 R, 3 R)$-taxifolin-3- $O$ - $\alpha$-L-rhamnoside or astilbin, is the major compound, whereas its intensity has de- creased in the chromatogram of fraction F4 as compared to the stable compound 5 (quercetin-3-O- $\alpha$-L-rhamnoside), and the intensity of the other isomers have increased. Probably, compounds 1,3 , and 4 should be considered as artefacts $[18,19]$. The question can be raised if these compounds may be responsible for or contribute to the activity claimed for B. benna in traditional medicine. Although no in vitro antiplasmodial activity has been reported for astilbin, a moderate activity was observed for taxifolin [20], and the same is true for quercetin [21]. After oral intake, the glycosides can be metabolized (hydrolyzed) in the gastrointestinal tract by gut flora, liberating potentially active aglycones or other metabolites that can be absorbed. Thus, it could be concluded that these flavonoid glycosides contribute, at least in part, to the traditional use against malaria. In a short time, without extensive and laborious purification, these compounds were identified by means of LC-SPE-NMR and priorities 

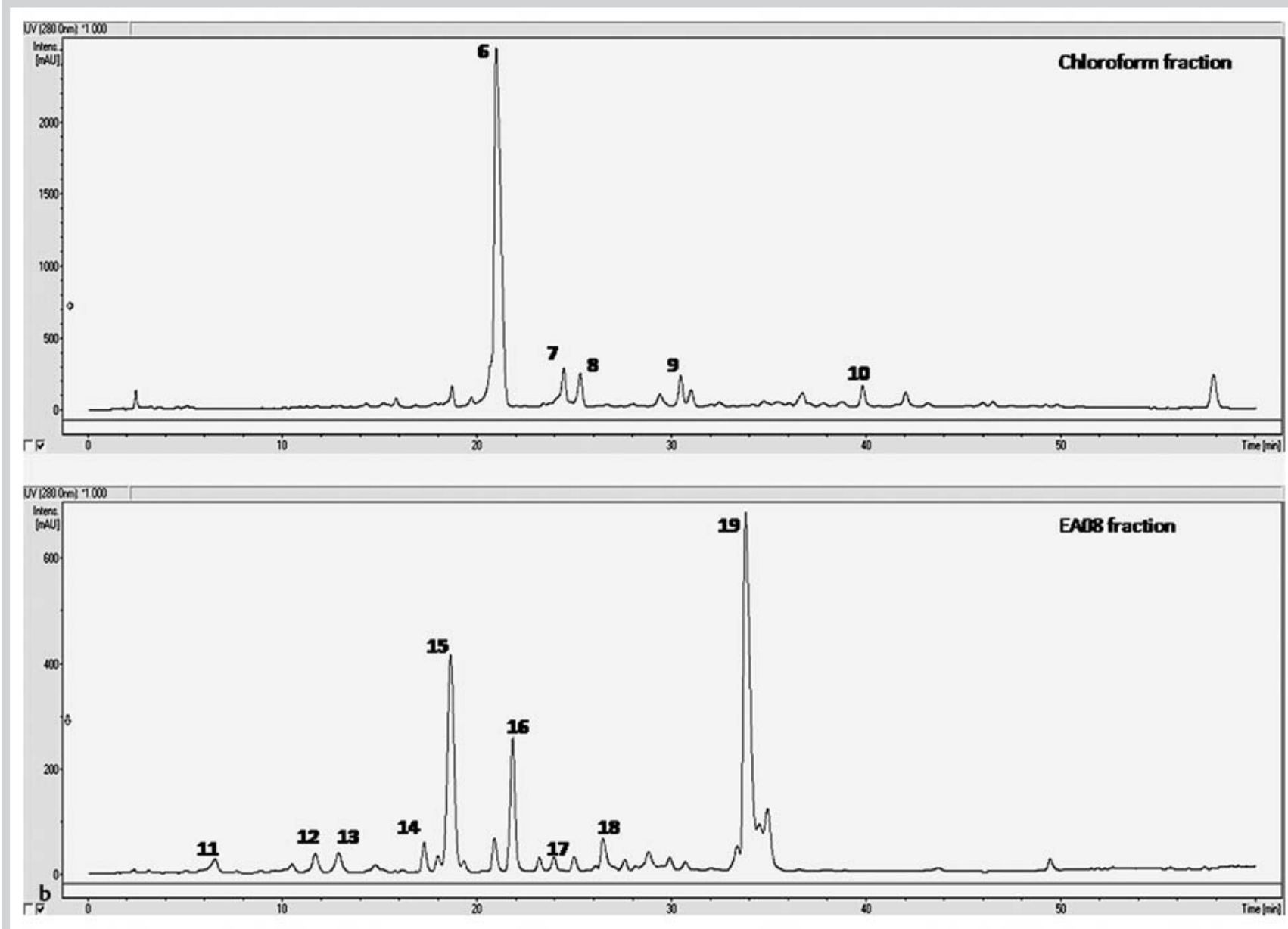

Fig. 4b HPLC profile of the chloroform fraction and fraction EA08 of $O$. kirkii using $0.05 \%$ TFA in water (A) and $\mathrm{MeOH}(B): 0$ min, 80:20 (A:B); 20 min,

Zorbax Eclipse XDB-C18 column, $5 \mu \mathrm{m}, 150 \times 4.6 \mathrm{~mm}$ with detection at $280 \mathrm{~nm}$.

$60: 40 ; 30 \mathrm{~min}, 57: 43 ; 65 \mathrm{~min}, 60: 40 ; 70 \mathrm{~min}, 0: 100$; at $1.0 \mathrm{~mL} / \mathrm{min}$ on a

could be set: at this stage of the research, Bafodeya benna could not be considered as a promising source of new lead compounds for the treatment of malaria.

Concerning Ormocarpum kirkii, the chloroform and EA08 fractions were selected for investigation based on their chromatographic profiles ( $\odot$ Fig. 4a). LC-SPE-NMR analysis of the chloroform fraction (O Fig. 4b) resulted in the identification of five compounds (6-10). Comparison of NMR and MS data with literature data showed that these compounds comprised (+)-chamaejasmin (6) [11], diphysolone (7) [22], glabroisoflavanone A (8) [23], sikokianin B (9) [24], and chamaejasmenin B (10) [25]. Compounds 7-10 were characterized for the first time in 0 . kirkii. Diphysolone was isolated before from Desmodium uncinatum and Diphysa robinioides. No optical rotation has been reported. Also in our LC-SPE-NMR setting, the optical rotation has not been measured. It should be noted that we have reported 4"-hydroxydiphysolone from 0 . kirkii [11]. For this compound the specific rotation was 0 , which implied a racemic compound. Glabroisoflavanone A was reported before from Glycyrrhiza glabra as a racemic compound [23]. Sikokianin B was reported before from Wikstroemia indica and W. sikokiana [24], and chamaejasmenin B from Stellera chamaejasme and Wikstroemia sikokiana [25]. LC-SPE-NMR analysis of fraction EA08 led to the isolation and characterization of ten peaks (11-19) ( $\odot$ Fig. 4b). Comparison of their NMR and MS spectra with literature data permitted these to be identified as 7-O- $\beta$-D-glucosyldiphysin (11) [11], montanoside (12) [26], naringin (13) [27], isovitexin (14) [11], and 7-O- $\beta$ D-glucosylchamaejasmin (19) [11]. Montanoside (12) and naringin (13) were isolated for the first time from O. kirkii. Montanoside was obtained before from Centaurea montana [26], while naringin is a quite common flavonoid.

Compounds 16-18 were found to be new. The molecular formula of compounds 15 and 16 was deduced as $\mathrm{C}_{42} \mathrm{H}_{42} \mathrm{O}_{20}$ by ${ }^{13} \mathrm{C}$ NMR and MS data. The NMR spectra of 15 and 16 were similar. Compound 15 was identified as 7,7 "-di- $O-\beta$-D-glucosylchamaejasmin by comparing the retention time with reference material and NMR data [11] ( $\bigcirc$ Fig. 5). By comparing the NMR spectra of compound 16 with those of $(+)$-chamaejasmin, isochamaejasmin, and compound 15 , it could be deduced that 16 should be 7,7 "-di- $O-\beta$ D-glucosyl-(-)-chamaejasmin ( 0 Fig. 6).

The molecular formula of compound $17\left(\mathrm{C}_{36} \mathrm{H}_{32} \mathrm{O}_{13}\right)$ was established by ${ }^{13} \mathrm{C}$ NMR and MS. The ${ }^{1} \mathrm{H}$ and ${ }^{13} \mathrm{C}$ NMR spectra of compound 17 displayed signals of a glucose moiety $\left(\delta_{\mathrm{H}} 4.97,3.30\right.$ 3.90 and $\delta_{\mathrm{C}} 101.6,78.3,77.9,74.8,71.3$, and 62.4$)$. Analysis of the ${ }^{1} \mathrm{H}$ and ${ }^{13} \mathrm{C}$ NMR spectra indicated that the NMR data of 17 (O Tables 1 and 2) resembled those of (I-3,II-3)-biliquiritigenin [11]. However, the ${ }^{13} \mathrm{C}$ NMR spectrum showed 30 resonances instead of 15 doubled signals besides those of glucose, due to the 

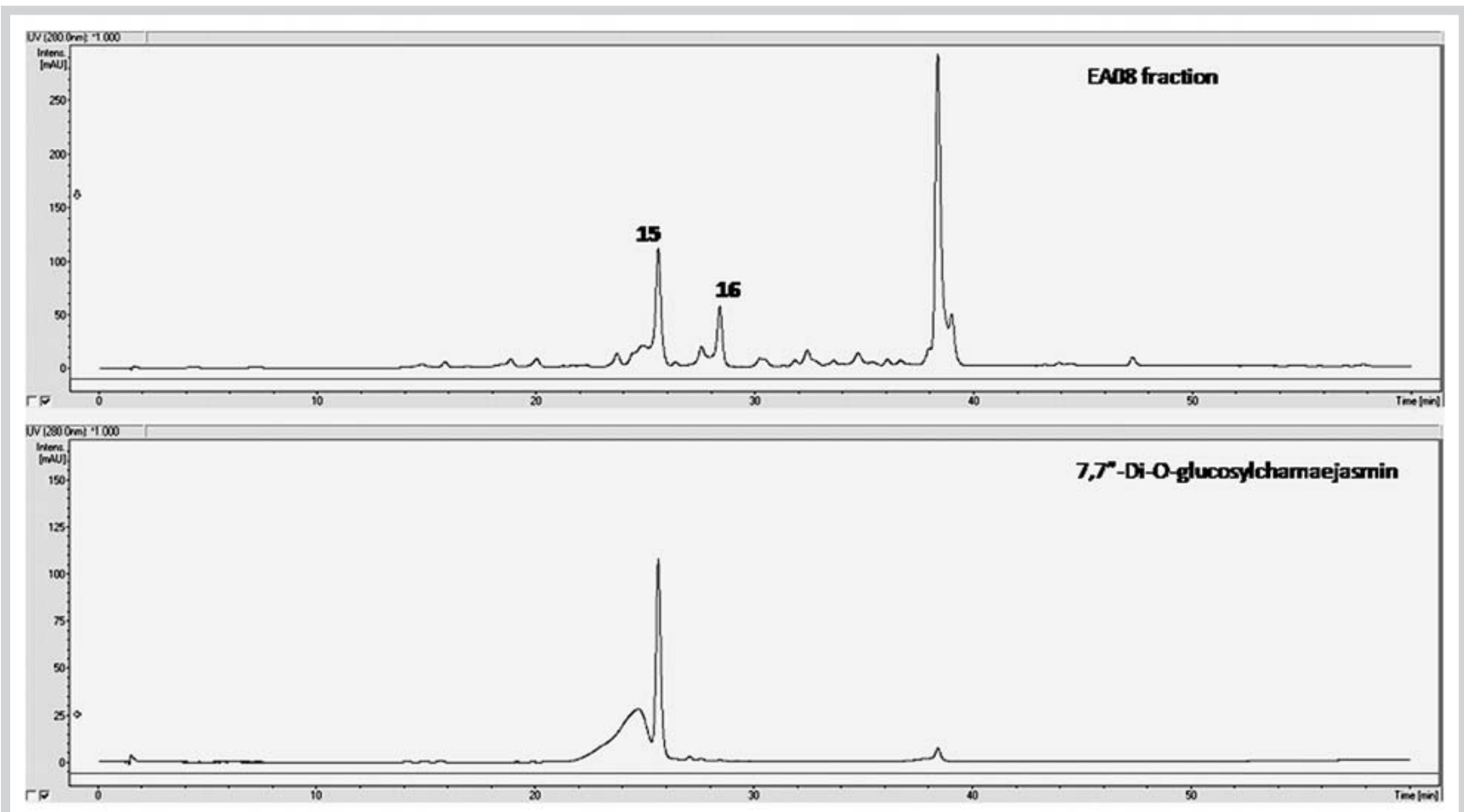

Fig. 5 HPLC profile of fraction EA08 of Ormocarpum kirkii compared to the chromatogram of 7,7"'-di-O- $\beta$-D-glucosylchamaejasmin using $0.05 \%$ TFA in water (A) and $\mathrm{MeOH}(B): 0$ min, 80:20 (A:B); 20 min, 60:40; 30 min, 57:43;
$65 \mathrm{~min}, 60: 40 ; 70 \mathrm{~min}, 0: 100$; at $1.0 \mathrm{~mL} / \mathrm{min}$ on a Zorbax Eclipse XDB-C18 column, $5 \mu \mathrm{m}, 150 \times 4.6 \mathrm{~mm}$ with detection at $280 \mathrm{~nm}$. asymmetry induced by the glucose moiety in the structure of compound 17. However, the key correlation between the anomeric proton $\left(\delta_{\mathrm{H}} 4.97\right)$ and $\mathrm{C}-7\left(\delta_{\mathrm{C}} 166.7\right)$ was not observed in the HMBC spectrum, due to the low concentration of the sample. Nevertheless, the NOESY correlation between the anomeric proton $\left(\delta_{\mathrm{H}} 4.97\right)$ and $\mathrm{H}-8\left(\delta_{\mathrm{H}} 6.62\right)$ indicated that the glycosidic moiety was linked to $\mathrm{C}-7$. Therefore, the structure of 17 was established as 7-O- $\beta$-D-glucosyl-(I-3,II-3)-biliquiritigenin.

The molecular formula of compound $\mathbf{1 8}$ was assigned as $\mathrm{C}_{36} \mathrm{H}_{30} \mathrm{O}_{15}$ by ${ }^{13} \mathrm{C}$ NMR and MS. In the ${ }^{13} \mathrm{C}$ NMR spectrum, 36 resonances were visible, revealing that this biflavonoid contained one glucose moiety. The NMR data of compound 18 were similar to those of apigeninyl-(I-3,II-3)-naringenin isolated from 0 . kirkii before [11], except for the signals due to the additional glucose group. The glucosyl moiety could be located at position C-6" based on the HMBC correlation observed between the anomeric proton $\left(\delta_{\mathrm{H}} 4.89\right)$ and $\mathrm{C}-6^{\prime \prime}\left(\delta_{\mathrm{C}} 109.2\right)$ as well as $\mathrm{C}-7$ " $\left(\delta_{\mathrm{C}} 165.6\right)$. Therefore, compound 18 was identified as isovitexin-(I-3,II-3)naringenin.

(+)-Chamaejasmin (7), which is the major constituent of the chloroform fraction, was reported to exhibit a moderate antiplasmodial activity [11]. Furthermore, sikokianin B (9) and chamaejasmenin B (10) were also reported to show antiplasmodial activity [24]. On the contrary, the major constituent of fraction EA08 (7-O- $\beta$-D-glucosylchamaejasmin [19]) and these minor constituents (7-O- $\beta$-D-glucosyldiphysin [11], isovitexin [14] and 7,7"-di$0-\beta$-D-glucosylchamaejasmin [15]) showed no antiplasmodial activity at all [11]. This is in agreement with the moderate activity of the chloroform fraction and the inactivity of fraction EA08 observed in our previous work [11]. Nevertheless, in the gastrointestinal tract chamaejasmin glycosides may be hydrolyzed, leading to additional amounts of chamaejasmin or other biflavonoid aglycones. Since the biflavonoids may not be absorbed as such, their metabolites may be responsible at least in part for the antimalarial activity attributed to Ormocarpum kirkii.

In conclusion, LC-SPE-NMR, in combination with LC-MS, is a powerful tool for the fast characterization of plant extracts. In this way priorities can be defined at an early stage of a fractionation procedure in order to avoid the isolation of common or uninteresting compounds. In addition, herbal medicinal products can be fully characterized, preceding their standardization, focusing not only on the major compounds but also on minor constituents that may contribute to the biological activity in an additive or even synergistic way.

\section{Acknowledgements}

$\nabla$

The Special Fund for Research of the University of Antwerp is acknowledged for granting a postdoctoral fellowship to Y.-J. Xu.

\section{Affiliations}

${ }^{1}$ Laboratory of Pharmacognosy and Pharmaceutical Analysis, Department of Pharmaceutical Sciences, University of Antwerp, Antwerp, Belgium

2 Nucleoside Research and Mass Spectrometry Unit, Department of Chemistry, Antwerp, Belgium

${ }^{3}$ Department of Pharmacognosy, School of Pharmacy, Muhimbili University of Health and Allied Sciences (MUHAS), Dar-Es-Salaam, Tanzania (present address)

${ }^{4}$ Département de Pharmacie, Faculté de Médecine, Pharmacie et Odontostomatologie, Université de Conakry; Centre de Recherche et de Valorisation des Plantes Médicinales de Dubréka, Conakry, Guinea 


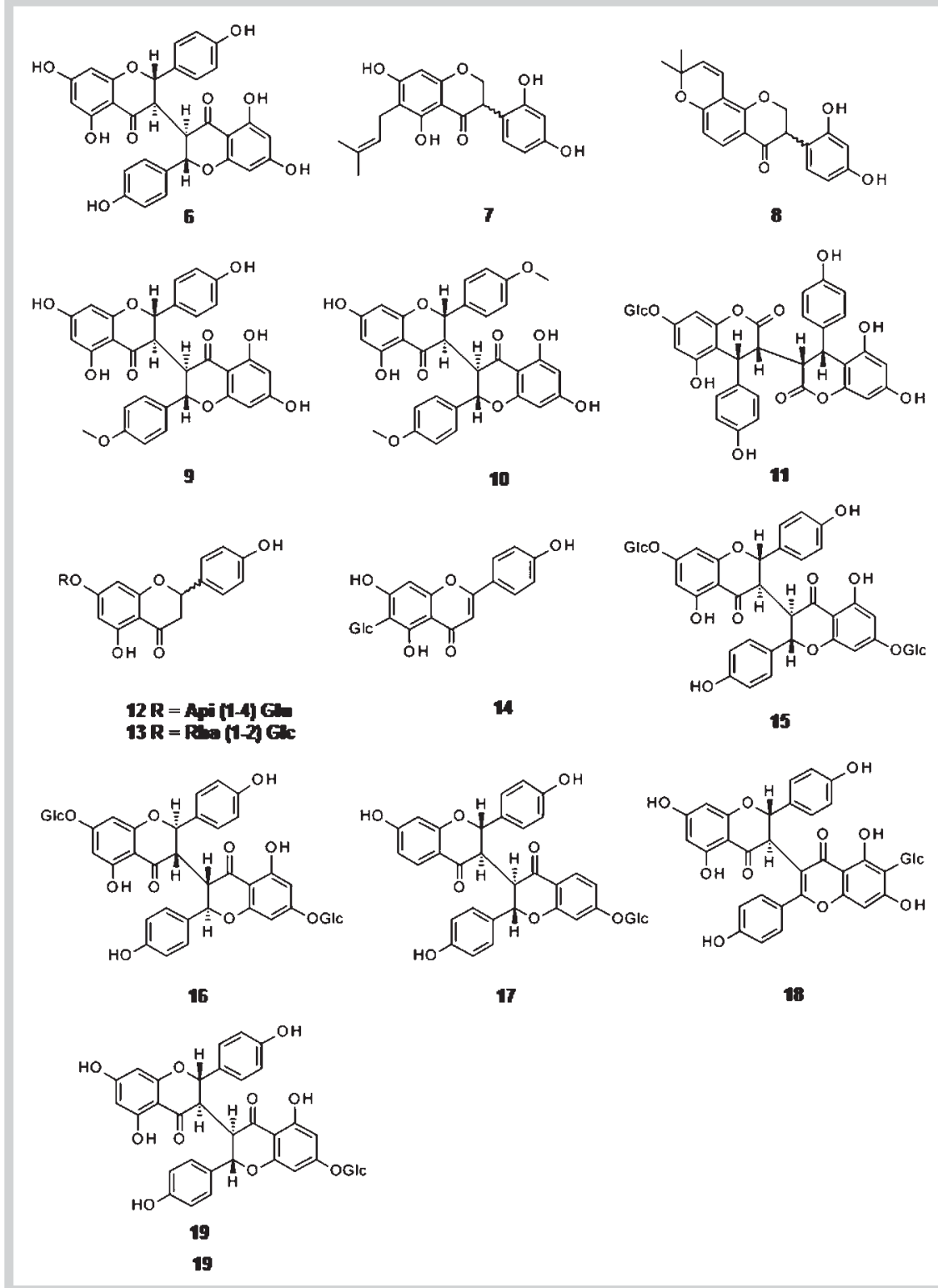

Fig. 6 Compounds 6-19 from Ormocarpum kirkii.

\section{References}

1 World Malaria Report 2008. Geneva: World Health Organization; 2008: viii-x. Available at http://whqlibdoc.who.int/publications/2008/ 9789241563697_eng.pdf

2 World Health Organization Fact Sheet No.134: Traditional Medicine. Geneva: World Health Organization; 2008

3 Vlietinck A, Pieters L, Apers S. Legal requirements for the quality of herbal substances and herbal preparations for the manufacturing of herbal medicinal products in the European Union. Planta Med 2009; 75: 683-688

4 Pieters L, Vlietinck A. Bioguided isolation of pharmacologically active plant components, still a valuable strategy for the finding of new lead compounds? J Ethnopharmacol 2005; 100: 57-60

5 Wolfender JL, Ndjoko K, Hostettmann K. Liquid chromatography with ultraviolet absorbance - mass spectrometric detection and with nuclear magnetic resonance spectroscopy: a powerful combination for the online structural investigation of plant metabolites. J Chromatogr A 2003; 1000: 437-455

6 Verpoorte R, Choi YH, Kim HK. NMR-based metabolomics at work in phytochemistry. Phytochem Rev 2007; 6: 3-14
7 Jaroszewski J. Hyphenated NMR methods in natural products research, part 2: HPLC-SPE-NMR and other trends in NMR hyphenation. Planta Med 2005; 71: 795-802

8 Magassouba FB, Diallo A, Kouyaté M, Mara F, Mara O, Bangoura O, Camara A, Traoré S, Diallo AK, Zaoro M, Lamah K, Diallo S, Camara G, Traoré S, Kéita A, Camara MK, Barry R, Kéita S, Oularé K, Barry MS, Donzo M, Camara K, Toté K, Berghe DV, Totté J, Pieters L, Vlietinck AJ, Baldé AM. Ethnobotanical survey and antibacterial activity of some plants used in Guinean traditional medicine. J Ethnopharmacol 2010; 128: 705708

9 Maregesi SM, Ngassapa OD, Pieters L, Vlietinck AJ. Ethnopharmacological survey of the Bunda district, Tanzania: plants used to treat infectious diseases. J Ethnopharmacol 2007; 113: 457-470

10 Maregesi S, Van Miert S, Pannecouque C, Feiz Haddad MH, Hermans N, Wright CW, Vlietinck AJ, Apers S, Pieters L. Screening of Tanzanian medicinal plants against Plasmodium falciparum and human immunodeficiency virus. Planta Med 2010; 76: 195-201

11 Dhooghe L, Maregesi S, Mincheva I, Ferreira D, Marais J, Lemiere F, Matheeusen A, Cos P, Maes L, Vlietinck A, Apers S, Pieters L. Antiplasmodial activity of (I-3,II-3)-biflavonoids from Ormocarpum kirkii. Phytochemistry 2010; 71: 785-791 
12 Kuspradini H, Mitsunaga T, Ohashi $H$. Antimicrobial activity against Streptococcus sobrinus and glucosyltransferase inhibitory activity of taxifolin and some flavanonol rhamnosides from kempas (Koompassia malaccensis) extracts. J Wood Sci 2009; 55: 308-313

13 Chosson E, Chaboud A, Chulia AJ, Raynaud J. Dihydroflavonol glycosides from Rhododendron ferrugineum. Phytochemistry 1998; 49: 14311433

14 Zhou X, Xu Q Li JX, Chen T. Structural revision of two flavanonol glycosides from Smilax glabra. Planta Med 2009; 75: 654-655

15 Cintra P, Malaspina O, Petacci F, Fernandes JB, Bueno OC, Vieira PC, Da Silva MFD. Toxicity of Dimorphandra mollis to workers of Apis mellifera. J Braz Chem Soc 2002; 13: 115-118

$16 \mathrm{Du}$ QZ, Li L, Jerz G. Purification of astilbin and isoastilbin in the extract of Smilax glabra rhizome by high-speed counter-current chromatography. J Chromatogr A 2005; 1077: 98-101

17 Arot LOM, Williams LAD. A flavonol glycoside from Embelia schimperi leaves. Phytochemistry 1997; 44: 1397-1398

18 Chen L, Yin Y, Yi HW, Xu Q Chen T. Simultaneous quantification of five major bioactive flavonoids in Rhizoma Smilacis Glabrae by high-performance liquid chromatography. J Pharm Biomed Anal 2007; 43: $1715-1720$

19 Kasai R, Hirono S, Chou WH, Tanaka O, Chen FH. Sweet dihydroflavonol rhamnoside from leaves of Engelhardtia chrysolepis, a Chinese folk medicine, Hung-qi. Chem Pharm Bull 1988; 36: 4167-4170
20 Kraft C, Jenett-Siems K, Siems K, Solis PN, Gupta MP, Bienzle U, Eich E. Andinermals A-C, antiplasmodial constituents from Andira inermis. Phytochemistry 2001; 58: 769-774

21 Gupta AM, Saxena S, Saxena M. Integrated ligand and structure based studies of flavonoids as fatty acid biosynthesis inhibitors of Plasmodium falciparum. Bioorg Med Chem Lett 2010; 20: 4779-4781

22 Tsanuo MK, Hassanali A, Hooper AM, Khan Z, Kaberia F, Pickett JA, Wadhams $L J$. Isoflavanones from the allelopathic aqueous root exudate of Desmodium uncinatum. Phytochemistry 2003; 64: 265-273

23 Kinoshita T, Tamura Y, Mizutani K. The isolation and structure elucidation of minor isoflavonoids from licorice of Glycyrrhiza glabra origin. Chem Pharm Bull 2005; 53: 847-849

24 Nunome S, Ishiyama A, Kobayashi M, Otoguro K, Kiyohara H, Yamada H, Omura $S$. In vitro antimalarial activity of biflavonoids from Wikstroemia indica. Planta Med 2004; 70: 76-78

25 Yang GH, Liao ZX, Xu ZY, Zhang HP, Chen DF. Antimitotic and antifungal C-3/C-3"-biflavanones from Stellera chamaejasme. Chem Pharm Bull 2005; 53: 776-779

26 Shoeb M, MacManus SM, Jaspars M, Trevidu J, Nahar L, Kong-Thoo-Lin P, Sarker SD. Montamine, a unique dimeric indole alkaloid, from the seeds of Centaurea montana (Asteraceae), and its in vitro cytotoxic activity against the $\mathrm{CaCo} 2$ colon cancer cells. Tetrahedron 2006; 62: 11172-11177

27 Liu L, Liu $Q$ Wu M, Zhang H. Study on powder characteristics and in vitro dissolution rate of Exocarpium Citri Grandis in different diameters. Guangdong Yaoxueyuan Xuebao 2010; 26: 20-22 